\title{
Research of Influence of Salivary and Oral Cleaning Hygiene on Indicators of Mineralization of Hard Tooth Tissues of Different Functional Groups
}

\author{
Alexandrov MT*, Dmitrieva EF, Artemova OA and Akhmedov AN \\ IM Sechenov First MSMU, Russia
}

\begin{abstract}
Introduction: In vitro, investigate by the method of Raman fluorescence spectroscopy the effect of saliva and oral hygiene products on the mineralization indices of various anatomical and topographic areas of teeth for their various functional groups, to substantiate its clinical feasibility and effectiveness.
\end{abstract}

Methods: In a preclinical in vitro study on 90 model test objects of teeth (incisors, premolars, and molars) removed according to clinical indications, a Raman fluorescence study of the degree of mineralization (Raman spectrum characteristics), dental hygiene conditions (plaque and intensity fluorescence) and evaluation of the effectiveness of remineralizing agents (films, suspensions) in various functional groups of teeth. For registration of the studied parameters, InSpektr M agro-industrial complex was used with a probe wavelength of $532 \mathrm{~nm}$. The advantages of Raman fluorescence spectroscopy for determining the degree of mineralization and the hygienic state of tooth hard tissues are objectivity (digital technology), expressivity, non-invasiveness, simple and non-invasive control the degree of mineralization / demineralization of the hard tissues of the tooth and its hygienic state, the possibility of documenting and storing information (creating a database).

Results: In the course of the study, a qualitative and quantitative analysis of the influence of saliva and oral hygiene products on the mineralization and hygienic condition of various functional groups of teeth was carried out.

KEYWORDS: Enamel; Saliva; Mineralization; Anatomical and topographic zone; Hard tooth tissues; Oral hygiene products; Raman fluorescence spectroscopy; Hygiene assessment

\section{INTRODUCTION}

Currently, dental caries is one of the most common dental diseases among children and adults in the Russian Federation. One of the local factors in the occurrence of caries is poor hygienic oral care, as well as a change in the quantitative and qualitative composition of the oral fluid [1].

In the system of caries prevention, the leading aspect is oral hygiene. The theoretical justification for using oral hygiene products to remineralize in the prevention of caries and mineralization of hard tissueš of the tooth is scientific research that confirms that the most important property of enamel is permeability, which is ensured by the presence of micro spaces filled with water in it,

Quick Response Code:

Address for correspondence: Aleksandrov Mikhail Timofeevich, MD, Professor, IM Sechenov First MSMU, Russia

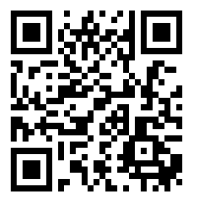

Received: November 21, 2019 Published: December 04, 2019

How to cite this article: Alexandrov MT, Dmitrieva EF, Artemova OA, Akhmedov AN. Research of Influence of Salivary and Oral Cleaning Hygiene on Indicators of Mineralization of Hard Tooth Tissues of Different Functional Groups. 2019 - 1(3) OAJBS.ID.000125. DOI: $10.38125 / \mathrm{OAJBS} .000125$ 
through which substances can penetrate as inorganic, and organic nature - depending on their polarity and size. The penetration and movement of ions in the aqueous phase of enamel is facilitated by osmotic pressure, which is the main mechanism of the process of remineralization and demineralization of hard tissues of the tooth. In this physiological process, the determining role is played by oral fluid (saliva), which is the main source for the entry of substances into the tooth structure [2-4]. However, the question that has not been studied is how to quickly, simultaneously and without changing the studied tooth structures carry out diagnostic measurements of its mineralization and plaque presence, and how oral hygiene products (different toothpastes and powders by the mechanism of action) and methods of their use affect the mineralization of hard tissues tooth and their hygiene status. Thus, it is of interest to study all three main factors affecting the mineralization of hard tooth tissues: saliva, hygiene products and methods for applying remineralizing tooth powders and pastes. This question is practically not covered in the literature.

Based on the presented problematic issues, it should be noted that in recent years, more and more interest in clinical and experimental medicine is caused by innovative diagnostic methods that allow to evaluate the mineralization of hard tissues of the tooth and bones, including when exposed to physical, chemical and biological factors at the level molecular transformations and, most importantly, non-invasive route [5]. These methods include Raman fluorescence spectroscopy, developed methodologically and methodically by MD, professor, state prize laureate of the Russian Federation Alexander M.T. It is believed that Raman spectroscopy makes it possible to objectively evaluate the spectral bands associated with specific chemical structures of tooth hard tissues $[6,7]$. Thus, this technology, at present, can be considered preferable in the study of remineralization of teeth [8-14]. In this regard, the goal of our study was a comprehensive study of the effect of saliva, oral hygiene products (toothpastes, toothbrushes) on the mineralization and hygienic conditions of various anatomical and topographic areas of teeth of various functional groups using Raman fluorescence spectroscopy. Summing up, it should be noted once again that Raman-fluorescence technologies are not presented in the literature that allow real-time, simultaneous assessment of both the hygienic state of hard tooth tissues and the degree of their mineralization. At the same time, such a clinically important aspect has not been studied as the effect of saliva and oral hygiene on the studied parameters of tooth hard tissues.

\section{MATERIAL AND METHODS}

In this in vitro preclinical study on model test objects of teeth removed for clinical reasons (incisors, premolars, molars), we evaluated the effect of saliva and oral hygiene products, an acidforming factor, and the effectiveness of remineralizing agents (films, suspensions) on mineralization indices and the presence of plaque of various anatomical and topographic areas of the teeth using the laser hardware-software complex Raman-fluorescence diagnostics "InSpektr M" with a probe wavelength I 532nm. The study was carried out based on preliminary in vitro experiments, where it was objectively revealed that the Raman spectra of teeth (tooth enamel) are adequate to those of a reference sample of hydroxylapatite - the HAP line. This result determined the choice of the presented methodology for solving the goals and objectives of the study. Using the InSpektr M agro-industrial complex, test objects (enamel, dentin, cement of the teeth under study) were exposed to low-intensity laser radiation of the visible range of $532 \mathrm{~nm}$. At the same time, they collected and processed the information received online. The measurements were performed in the contact-stable position of the object (tooth) to the radiation source. Each spectral measurement corresponded to Msr of 500 measurements, with a duration of one measurement $-100 \mu$ s (based on the accumulated signal accumulation time necessary for its visualization and measurement in the experiment). The total time of one measurement corresponded to $2.5-3 \mathrm{~min}$. In total, in the preclinical study used 90 test objects of teeth, 30 from each functional group (incisors - 30, premolars - 30, molars - 30), removed according to clinical indications.

To quantify the intensity of Raman radiation at a wavelength of hydroxylappatite of $963 \mathrm{~cm}^{-1}$ (in absolute units), we measured the parameters at the maximum and minimum of its spectral power. The resulting difference (rel. Units) was taken as the intensity of Raman characterizing the presence and concentration of hydroxylapatite in the enamel, dentin and cement of the studied teeth ( $\mathrm{M}$ cf.). To quantify fluorescence intensity (as characteristics of plaque), its maximum values were measured.

Colgate total toothpaste was used as a hygiene product for cleaning teeth, and freshly squeezed lemon juice was used as an acid factor.

\section{RESULTS}

From the results it follows that the initial indicators of the intensity of the Raman radiation, characterizing the salinity of the incisors, in the presence of saliva increase and amounted to 1218abs. units, at the initial level of 645 abs. units (Table 1,2). The use of tooth powder when cleaning teeth leads to superficial demineralization (859 abs. Units). When organic acids act on enamel, it dissolves (216abs. Units). Plaque indices increase with prolonged application of saliva ( $1^{\text {st }}$ day) and significantly decrease with almost the same time application of organic acid almost twice. Similar results were obtained for premolars, the initial level of Raman radiation intensity was 218 abs. units, in the presence of saliva, it increased (706abs. units), with the use of tooth powder decreased to 321abs. units The action of the acid caused a deep demineralization of enamel (94abs. Units). The fluorescence indices had similar changes. For the molar-primary level of intensity of the Raman radiation of the molars was 365abs. units, in the presence of saliva, it doubled (681abs. units), with the use of tooth powder it decreased to 194abs. units The action of the acid caused a deep demineralization of enamel (191abs. Units). In terms of fluorescence, similarly. From the presented table it follows that the greatest salinity (according to the intensity of the Raman line (y $=$ ) at a wavelength $\left(\mathrm{x}=963 \mathrm{~cm}^{-1}\right)$ is tooth enamel (cutting edge), the smallest is the tooth neck. It is shown that the application of saliva increases the salinity of hard tissues tooth and at the same time increases the concentration of plaque (according to its fluorescence intensity). And, most importantly, in all cases of using a toothbrush and toothpaste leads to a significant demineralization of tooth hard tissues (up to 50\%). This phenomenon requires a review of creatures saving technologies their hygienic handling and application thereto of additional remineralizing agents for fast recovery of the strength characteristics of the tooth (mineralization).

In this regard, we decided to study the effect of remineralizing agents (films and suspension) on the mineralization of tooth enamel. From the presented results it is seen that after application with natural plates with calcium and a suspension of nano-HAP, the level of mineralization increased by more than 2 times (Table 3). This fact is of great clinical importance both in the scientific and in the application. 
Table 1: The effect of saliva, hygiene products and acid-forming preparations on the degree of mineralization of the enamel of incisors, canines, premolars and molars.

\begin{tabular}{|c|c|c|c|c|}
\hline Study Object(N) & $\begin{array}{l}\text { Localization of } \\
\text { Measurements }\end{array}$ & $\begin{array}{c}\text { Upper Peak (Signal } \\
\text { Intensity at Maximum/ } \\
\text { Wavelength at Maximum) }\end{array}$ & $\begin{array}{c}\text { Lower Peak (Signal } \\
\text { Intensity at Minimum/ } \\
\text { Wavelength at Minimum }\end{array}$ & $\begin{array}{c}\text { Raman Intensity } \\
\text { (Relative Units (M. } \\
\text { Average)) }\end{array}$ \\
\hline \multirow{3}{*}{ Incisors $\mathrm{N}=30$} & Cutting edge & $y=11134, x=963 \mathrm{~cm}^{-1}$ & $y=8079, x=963 \mathrm{~cm}^{-1}$ & $y=3058, x=963 \mathrm{~cm}^{-1}$ \\
\hline & Equator & $y=12644, x=963 \mathrm{~cm}^{-1}$ & $y=8843, x=963 \mathrm{~cm}^{-1}$ & $y=3801, x=963 \mathrm{~cm}^{-1}$ \\
\hline & $\begin{array}{l}\text { Cervical region, Vestibular } \\
\text { Surface }\end{array}$ & $y=9867, x=963 \mathrm{~cm}^{-1}$ & $y=6875, x=963 \mathrm{~cm}^{-1}$ & $y=2992, x=963 \mathrm{~cm}^{-1}$ \\
\hline \multirow{3}{*}{ Canine $\mathrm{N}=30$} & Cutting edge & $y=13253, x=963 \mathrm{~cm}^{-1}$ & $y=8574, x=963 \mathrm{~cm}^{-1}$ & $y=4679, x=963 \mathrm{~cm}^{-1}$ \\
\hline & Equator & $y=14387, x=963 \mathrm{~cm}^{-1}$ & $y=8596, x=963 \mathrm{~cm}^{-1}$ & $y=5791, x=963 \mathrm{~cm}^{-1}$ \\
\hline & $\begin{array}{l}\text { Cervical region, Vestibular } \\
\text { surface }\end{array}$ & $y=11098, x=963 \mathrm{~cm}^{-1}$ & $y=8436, x=963 \mathrm{~cm}^{-1}$ & $y=2662, x=963 \mathrm{~cm}^{-1}$ \\
\hline \multirow{3}{*}{ Premolars N=30 } & Occlusal surface & $y=12487, x=963 \mathrm{~cm}^{-1}$ & $y=9576, x=963 \mathrm{~cm}^{-1}$ & $y=2911, x=963 \mathrm{~cm}^{-1}$ \\
\hline & Equator & $y=14376, x=963 \mathrm{~cm}^{-1}$ & $y=9875, x=963 \mathrm{~cm}^{-1}$ & $y=4501, x=963 \mathrm{~cm}^{-1}$ \\
\hline & $\begin{array}{l}\text { Cervical region, Vestibular } \\
\text { Surface }\end{array}$ & $y=10956, x=963 \mathrm{~cm}^{-1}$ & $y=8457, x=963 \mathrm{~cm}^{-1}$ & $y=2499, x=963 \mathrm{~cm}^{-1}$ \\
\hline \multirow{3}{*}{ Molars N=30 } & Occlusal surface & $y=17865, x=963 \mathrm{~cm}^{-1}$ & $y=15967, x=963 \mathrm{~cm}^{-1}$ & $y=1898, x=963 \mathrm{~cm}^{-1}$ \\
\hline & Equator & $y=17840, x=963 \mathrm{~cm}^{-1}$ & $y=14329, x=963 \mathrm{~cm}^{-1}$ & $y=3511, x=963 \mathrm{~cm}^{-1}$ \\
\hline & $\begin{array}{c}\text { Cervical region, Vestibular } \\
\text { Surface }\end{array}$ & $y=15439, x=963 \mathrm{~cm}^{-1}$ & $y=14326, x=963 \mathrm{~cm}^{-1}$ & $y=1113, x=963 \mathrm{~cm}^{-1}$ \\
\hline
\end{tabular}

Table 2: Averaged indicators ( $M$ cf.) of the spectral characteristics of the tooth for various anatomical and topographic areas under the influence of saliva and hygiene products.

\begin{tabular}{|c|c|c|c|c|c|c|}
\hline & & & $\begin{array}{c}\text { Upper Peak (signal } \\
\text { intensity at maximum } \\
\text { / wavelength at } \\
\text { maximum }\end{array}$ & $\begin{array}{c}\text { Lower Level (Signal } \\
\text { Intensity at Minimum } \\
\text { / Wavelength at } \\
\text { Maximum) }\end{array}$ & $\begin{array}{l}\text { Raman Intensity } \\
\text { / Absolute Units } \\
\text { / Maximum } \\
\text { Wavelength }\end{array}$ & $\begin{array}{l}\text { Maximum } \\
\text { Fluorescence } \\
\text { Intensity }\end{array}$ \\
\hline \multirow{7}{*}{ Tooth neck } & \multicolumn{2}{|c|}{$\begin{array}{l}\text { The initial level of tooth } \\
\text { mineralization }\end{array}$} & $y=3720, x=963 \mathrm{~cm}^{-1}$ & $y=3559, x=963 \mathrm{~cm}^{-1}$ & $y=160, x=963 \mathrm{~cm}^{-1}$ & $y=4362$ \\
\hline & \multicolumn{2}{|c|}{ Exposure in saliva 1 day } & $y=4593, x=963 \mathrm{~cm}^{-1}$ & $y=4384 x=963 \mathrm{~cm}^{-1}$ & $y=209, x=963 \mathrm{~cm}^{-1}$ & $y=5351$ \\
\hline & \multirow{5}{*}{$\begin{array}{c}\text { Toothpaste } \\
\text { brushing }\end{array}$} & $1 \mathrm{~min}$ & $y=3191, x=963 \mathrm{~cm}^{-1}$ & $y=3061, x=963 \mathrm{~cm}^{-1}$ & $y=129, x=963 \mathrm{~cm}^{-1}$ & $y=4759$ \\
\hline & & $2 \mathrm{~min}$ & $y=3252, x=963 \mathrm{~cm}^{-1}$ & $y=3106 x=963 \mathrm{~cm}^{-1}$ & $y=145, x=963 \mathrm{~cm}^{-1}$ & $y=3906$ \\
\hline & & $3 \mathrm{~min}$ & $y=3261, x=963 \mathrm{~cm}^{-1}$ & $y=3117, x=963 \mathrm{~cm}^{-1}$ & $y=143, x=963 \mathrm{~cm}^{-1}$ & $y=3853$ \\
\hline & & $4 \mathrm{~min}$ & $y=3067, x=963 \mathrm{~cm}^{-1}$ & $y=2926 x=963 \mathrm{~cm}^{-1}$ & $y=140, x=963 \mathrm{~cm}^{-1}$ & $y=3639$ \\
\hline & & $5 \mathrm{~min}$ & $y=3065, x=963 \mathrm{~cm}^{-1}$ & $y=2880 x=963 \mathrm{~cm}^{-1}$ & $y=184, x=963 \mathrm{~cm}^{-1}$ & $y=3632$ \\
\hline \multirow{7}{*}{ Equator } & \multicolumn{2}{|c|}{$\begin{array}{l}\text { The initial level of tooth } \\
\text { mineralization }\end{array}$} & $y=3360, x=963 \mathrm{~cm}^{-1}$ & $y=2969, x=963 \mathrm{~cm}^{-1}$ & $y=391, x=963 \mathrm{~cm}^{-1}$ & $y=3965$ \\
\hline & \multicolumn{2}{|c|}{ Exposure in saliva 1 day } & $y=5111, x=963 \mathrm{~cm}^{-1}$ & $y=4302 x=963 \mathrm{~cm}^{-1}$ & $y=808, x=963 \mathrm{~cm}^{-1}$ & $y=5921$ \\
\hline & \multirow{5}{*}{$\begin{array}{l}\text { Toothpaste } \\
\text { brushing }\end{array}$} & $1 \mathrm{~min}$ & $y=3869, x=963 \mathrm{~cm}^{-1}$ & $y=3458, x=963 \mathrm{~cm}^{-1}$ & $y=410, x=963 \mathrm{~cm}^{-1}$ & $y=4610$ \\
\hline & & $2 \mathrm{~min}$ & $y=3883, x=963 \mathrm{~cm}^{-1}$ & $y=3330 x=963 \mathrm{~cm}^{-1}$ & $y=552, x=963 \mathrm{~cm}^{-1}$ & $y=4508$ \\
\hline & & $3 \min$ & $y=3396, x=963 \mathrm{~cm}^{-1}$ & $y=2991, x=963 \mathrm{~cm}^{-1}$ & $y=405, x=963 \mathrm{~cm}^{-1}$ & $y=4044$ \\
\hline & & $4 \mathrm{~min}$ & $y=3358, x=963 \mathrm{~cm}^{-1}$ & $y=2958 x=963 \mathrm{~cm}^{-1}$ & $y=399, x=963 \mathrm{~cm}^{-1}$ & $y=3500$ \\
\hline & & $5 \mathrm{~min}$ & $y=3548, x=963 \mathrm{~cm}^{-1}$ & $y=3190 x=963 \mathrm{~cm}^{-1}$ & $y=357, x=963 \mathrm{~cm}^{-1}$ & $y=3449$ \\
\hline \multirow{7}{*}{$\begin{array}{l}\text { Tooth enamel } \\
\text { cutting edge }\end{array}$} & \multicolumn{2}{|c|}{ Baseline } & $y=4934, x=963 \mathrm{~cm}^{-1}$ & $y=4404, x=963 \mathrm{~cm}^{-1}$ & $y=529, x=963 \mathrm{~cm}^{-1}$ & $y=6502$ \\
\hline & \multicolumn{2}{|c|}{ Exposure in saliva 1 day } & $y=6539, x=963 \mathrm{~cm}^{-1}$ & $y=5803 x=963 \mathrm{~cm}^{-1}$ & $y=735, x=963 \mathrm{~cm}^{-1}$ & $y=8719$ \\
\hline & \multirow{5}{*}{$\begin{array}{c}\text { Toothpaste } \\
\text { brushing }\end{array}$} & $1 \mathrm{~min}$ & $y=5787, x=963 \mathrm{~cm}^{-1}$ & $y=5207, x=963 \mathrm{~cm}^{-1}$ & $y=580, x=963 \mathrm{~cm}^{-1}$ & $y=7129$ \\
\hline & & $2 \mathrm{~min}$ & $y=5390, x=963 \mathrm{~cm}^{-1}$ & $y=5301 x=963 \mathrm{~cm}^{-1}$ & $y=88, x=963 \mathrm{~cm}^{-1}$ & $y=5989$ \\
\hline & & $3 \mathrm{~min}$ & $y=5165, x=963 \mathrm{~cm}^{-1}$ & $y=4705, x=963 \mathrm{~cm}^{-1}$ & $y=459, x=963 \mathrm{~cm}^{-1}$ & $y=5788$ \\
\hline & & $4 \mathrm{~min}$ & $y=4381, x=963 \mathrm{~cm}^{-1}$ & $y=3787 x=963 \mathrm{~cm}^{-1}$ & $y=593, x=963 \mathrm{~cm}^{-1}$ & $y=5540$ \\
\hline & & $5 \mathrm{~min}$ & $y=4205, x=963 \mathrm{~cm}^{-1}$ & $y=3762 x=963 \mathrm{~cm}^{-1}$ & $y=443, x=963 \mathrm{~cm}^{-1}$ & $y=5238$ \\
\hline
\end{tabular}


Table 3: Spectral characteristics of the enamel of the incisors before and after the action of acid-forming preparations, as well as after application with natural plates with calcium and a suspension of $30 \%$ nano-HAP.

\begin{tabular}{|c|c|c|c|c|}
\hline Object of Study $\mathbf{N}=\mathbf{3 0}$ & $\begin{array}{c}\text { Upper Peak (signal } \\
\text { intensity at maximum } \\
\text { / wavelength at } \\
\text { maximum }\end{array}$ & $\begin{array}{c}\text { Lower Level (Signal } \\
\text { Intensity at Minimum } \\
\text { / Wavelength at } \\
\text { Maximum) }\end{array}$ & $\begin{array}{c}\text { Raman Intensity / } \\
\text { Absolute Units }\end{array}$ & $\begin{array}{c}\text { Fluorescence } \\
\text { Intensity }\end{array}$ \\
\hline $\begin{array}{c}\text { Enamel after brushing your teeth } \\
\text { (incisors, fangs, premolars, molars) }\end{array}$ & $\mathrm{y}=7878, \mathrm{x}=963 \mathrm{~cm}^{-1}$ & $\mathrm{y}=7317, \mathrm{x}=963 \mathrm{~cm}^{-1}$ & $\mathrm{y}=560, \mathrm{x}=963 \mathrm{~cm}^{-1}$ & $\mathrm{y}=7467$ \\
\hline Enamel exposure in acid (1 day) & $\mathrm{y}=3200, \mathrm{x}=963 \mathrm{~cm}^{-1}$ & $\mathrm{y}=3052, \mathrm{x}=963 \mathrm{~cm}^{-1}$ & $\mathrm{y}=148, \mathrm{x}=963 \mathrm{~cm}^{-1}$ & $\mathrm{y}=3950$ \\
\hline Enamel plate application & $\mathrm{y}=7239, \mathrm{x}=963 \mathrm{~cm}^{-1}$ & $\mathrm{y}=6920, \mathrm{x}=963 \mathrm{~cm}^{-1}$ & $\mathrm{y}=319, \mathrm{x}=963 \mathrm{~cm}^{-1}$ & $\mathrm{y}=9937$ \\
\hline $\begin{array}{c}\text { Enamel after a course of suspension } \\
30 \% \text { with nano-HAP }\end{array}$ & $\mathrm{y}=3493, \mathrm{x}=963 \mathrm{~cm}^{-1}$ & $\mathrm{y}=3156, \mathrm{x}=963 \mathrm{~cm}^{-1}$ & $\mathrm{y}=337, \mathrm{x}=963 \mathrm{~cm}^{-1}$ & $\mathrm{y}=4139$ \\
\hline
\end{tabular}

\section{DISCUSSION}

From the data presented it follows that in all groups of teeth (incisors, premolars, molars) there is an increase in the level of mineralization two and three times in the presence of saliva and is 1218 - 706 - 681 abs. units, at the initial level 645 - 218 - 365abs. units The use of toothpaste when cleaning teeth leads to superficial demineralization (859 - 321 - 194abs.). Under the influence of organic acids on enamel, its dissolution (demineralization) takes place, apparently accompanied by a change in the shape, size and orientation of hydroxyapatite crystals (216 - 94 - 191abs. Units, which is more than 5 times lower than salinity in the presence of saliva). The reason for the rapid penetration of organic acids into the enamel is dislocations in the crystal lattice of enamel, the so-called vacant places and defects - the absence of an atom or atomic columns. When assessing the fluorescence intensity, which corresponds to the presence of plaque, it was found that plaque concentration and fluorescence intensity are dependent, and this dependence is close to linear.

In addition, it was shown that when observing the studied parameters during the day, we can conclude that plaque does not interfere with mineralization in the presence of saliva. In the presence of acid (citric acid), mineralization of the hard tissues of the tooth appears to be reduced and microbial growth is inhibited. It also follows from the tables that during brushing, the fluorescence intensity increased, which, apparently, indicates the detection of a microbial plaque under plaque. Thus, Raman-fluorescence spectroscopy shows integrated fluorescence in plaque and plaque.

In general, the clinical significance of the results obtained in vitro well explains the negative effect on the degree of mineralization of teeth (in decreasing order): acids, toothpastes and the positive effect (in decreasing) of saliva and toothpastes. Thus, the use of toothbrushes, apparently, does not contribute to mineralization, although they improve the hygienic condition of the oral cavity.

\section{CONCLUSION}

According to the literature, many researchers agree on the need for high-quality daily hygiene [15,16], remineralizing therapy [17], etc. As our study showed, the use of toothpastes as oral hygiene leads to a decrease in mineralization on the one hand, with on the other hand, there is a decrease in fluorescence intensity, which indicates the removal of soft dental deposits. The mineralizing potential of saliva is also confirmed by our results. Also, our study of the evaluation of remineralizing drugs showed their high efficiency. The data obtained indicate that Raman technologies allow expressly, almost online, "in place" to assess both the degree of mineralization of hard tissues of the tooth, and simultaneously detect the presence and degree of activity of plaque, as well as conduct a comparative assessment of the effects of various physical, chemical and biological factors affecting the mineralization/demineralization of teeth. It has been shown that a revision of existing technologies for hygienic tooth processing and the additional use of remineralizing drugs to quickly restore the strength characteristics of a tooth (its mineralization) are necessary.

\section{ACKNOWLEDGMENT}

The study had no sponsorship.

\section{CONFLICT OF INTEREST}

The authors declare no conflict of interest.

\section{REFERENCES}

1. Volkova Ed EA, Yanushevich OO (2013) Therapeutic dentistry. Diseases of the teeth at 3 hours. Part 1. GEOTAR-Media, Russia.

2. Bezrukov SG, Galkina OP (2014) The prevalence and intensity of dental caries depending on the functional properties of the oral fluid in patients with juvenile rheumatoid arthritis. Sovremennaya stomatologiya 2(59): 67-68.

3. Leontiev VK, Pakhomov GN (2006) Prevention of dental diseases. Russia.

4. Okushko VR (2008) Fundamentals of tooth physiology. Russia.

5. Krasnikova OV, Runova OA, Gordetsov AS (2015) Study of the crystal chemical composition of tooth tissues by infrared spectroscopy. Collection of articles of the International scientific-practical conference, Patterns and trends of science, Russia, 83: 6.

6. Tramini P, Bonnet B, Sabatier R, Maury L (2001) A method of age estimation using Raman microspectrometry imaging of the human dentin. Forensic Sci Int 118(1): 1-9.

7. Penel G, Leroy G, Rey C, Bres E (1998) Micro-Raman spectral study of the PO4 and CO3 vibrational modes in synthetic and biological apatites. Calcif Tissue Int 63(6): 475-481.

8. Miyazaki M, Onose H, Moore BK (2002) Analysis of the dentin-resin interface by use of laser Raman spectroscopy. Dent Mater 18(8): 576580 .

9. Ko AC, Hewko M, Sowa MG, Dong CC, Cleghorn B, et al. (2008) Early dental caries detection using a fibre-optic coupled polarization-resolved Raman spectroscopic system. Opt Express 16(9): 6274-6284.

10. Ko AC, Choo-Smith LP, Hewko M, Sowa MG, Dong CC, et al. (2006) Detection of early dental caries using polarized Raman spectroscopy. Opt Express 14(1): 203-215.

11. Yang S, Li B, Akkus A, Akkus O, Lang L (2014) Wide-field Raman imaging of dental lesions. Analyst 139(12): 3107-3114.

12. Ionita I (2009) Diagnosis of tooth decay using polarized micro-Raman confocal spectroscopy. Rom Rep Phys 61(3): 567-574. 
13. Timchenko EV, Timchenko PE, Volova LT, Rosenbaum AY, Kulabukhova AY (2016) Analysis of tooth tissues using Raman spectroscopy. J Phys Conf Ser 769: 012047.

14. Penel G, Delfosse C, Descamps M, Leroy G (2005) Composition of bone and apatite biomaterials as revealed by intravital Raman microspectroscopy. Bone 36(5): 893-901.

15. Mikheykina NI (2015) Analysis of indicators of the state of organs and tissues of the oral cavity of caries-resistant and carioscopic individuals in the dynamics of preventive measures. Byulleten' VostochnoSibirskogo nauchnogo tsentra Sibirskogo otdeleniya Rossiǔskol̆ akademii meditsinskikh nauk. 101(1): 29-33.

16. Nagaytseva EA (2016) Oral hygiene as a prevention of dental diseases. Mezhdunarodnyĭ studencheskiĭ nauchnyĭ vestnik. 2: 41-47.

17. Fattal RK, Ammaev MG, Melekhov SV (2015) Efficiency of modern microinvasive methods of treatment of initial dental caries depending on the level of oral hygiene of the patient. Dental forum 56(1): 5-8. 